\title{
Studies on Electrolytic Characteristics of Acetic Acid Formation in Sodium Acetate Electrolysis*
}

\author{
Tamotsu EGUCHI**
}

Electrolysis of sodium acetate to recover $\mathrm{HOAc}$ and $\mathrm{NaOH}$ is a very interesting problem in the Vinylon (synthetic fiber) industry ${ }^{1}$. Great many reports on alkali acetate electrolysis have referred to the Kolbe electro-synthesis ${ }^{2}$ and the allied reactions (for example, Hofer-Moest reactions ${ }^{3)}$, ester formation $^{4}$, aldehyde formation ${ }^{5}$ ) and so on) or their reaction mechanisms (for example, discharged ion theory ${ }^{2), 3)}$, acyl peroxide theor $\mathrm{y}^{2,3)}$ and hydrogen peroxide theor $\mathrm{y}^{2,3)}$ ). However, there are no reports on the recovery of $\mathrm{HOAc}$ and $\mathrm{NaOH}$ by electrolysing the $\mathrm{NaOAc}$ solution.

The first purpose of this report ${ }^{1)}$ is to investigate whether the electrolysis to obtain HOAc alone with a high yield is possible or not (excluding Kolbe reaction, Hofer-Moest reaction and so on), from electrolysis of sodium acetate solution. The second purpose is to find out the characteristics of the reaction of HOAc formation and to obtain the suitable anode material, at ordinary electrolytic conditions, considering the appropriate mechanism of anode phenomena.

Fig. 1 is the diaphragm cell, in which the anode is a nickel plate or a magnetite cylinder, and the cathode is mercury ${ }^{7)}$. The quantity of electricity was measured by a water coulometer ${ }^{8}$. The electrolysis was carried out at ordinary conditions $\left(\mathrm{NaOAc}=200-300 \mathrm{~g} / 1, D_{A}=10-15 \mathrm{~A} / \mathrm{dm}^{2}\right.$, at room temp.). Gas evolved at the anode was analyzed by means of a Hempel or a Göckel apparatus. Gas absorption was carried out systematically as the following order ${ }^{11), 12}$.

1. $\mathrm{CO}_{2}\left(30 \% \mathrm{KOH}\right.$ sol.), 2. $\mathrm{O}_{2}$ (alkaline pyrogallol sol.), 3. $\mathrm{C}_{2} \mathrm{H}_{4}\left(\mathrm{KBr}-\mathrm{Br}_{2}\right.$ in water), 4. $\mathrm{CO}$ (ammonia + Cucl sol.), 5. $\mathrm{H}_{2}$ (colloidal palladium), 6. $\mathrm{C}_{2} \mathrm{H}_{6}$ or $\mathrm{CH}_{4}$ (explosion method with $\mathrm{O}_{2}$ gas).

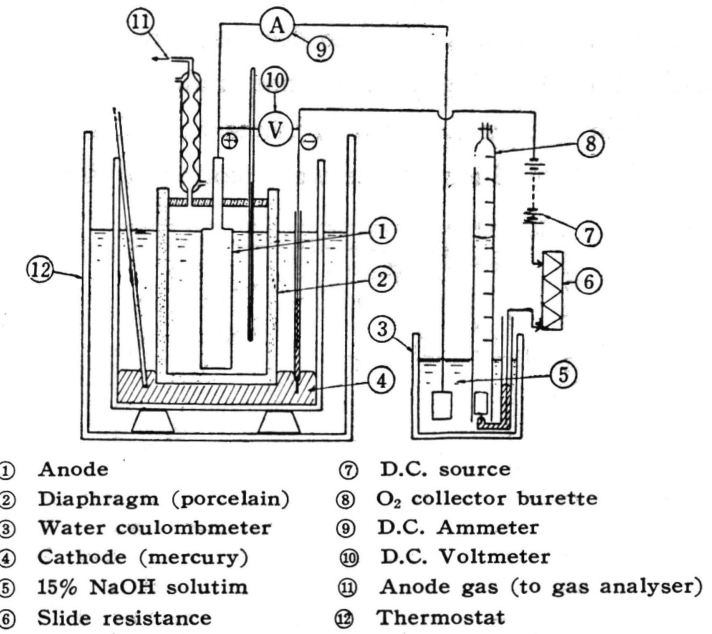

Fig. 1 Electrolysis equipment

It was found that the amounts of the gases besides $\mathrm{O}_{2}, \mathrm{CO}_{2}$ and $\mathrm{C}_{2} \mathrm{H}_{6}$ were negligibly small through out this experiment. The material loss of acetyl radical (100-S) was calculated by Eq. (4), considering the three main anode reactions Eqs. (1), (2) and (3).

* Studies on the Electrolysis of Sodium Acetate Solution (Part 1)

** Research Laboratory, Kurashiki Rayon Co., Kurashiki, Okayama

The original written in Japanese can be seen in J. Electrochem. Soc. Japan 28, 664 (1960). 


$$
\begin{aligned}
& \left.\begin{array}{l}
2 \mathrm{OH}^{-}+2 \mathrm{Fr} \rightarrow \mathrm{H}_{2} \mathrm{O}+1 / 2 \mathrm{O}_{2} \\
2 \mathrm{CH}_{3} \mathrm{COO}^{-}+2 \mathrm{H}^{+} \rightarrow 2 \mathrm{CH}_{3} \mathrm{COOH}
\end{array}\right\} \\
& 2 \mathrm{CH}_{3} \mathrm{COO}^{-}+2 \mathrm{Fr} \rightarrow \mathrm{C}_{2} \mathrm{H}_{6}+2 \mathrm{CO}_{2} \text { (Kolbe react.) } \\
& 2 \mathrm{CH}_{3} \mathrm{COO}^{-}+2 \mathrm{OH}^{-}+4 \mathrm{Fr} \rightarrow 2 \mathrm{CH}_{3} \mathrm{OH}+\mathrm{CO}_{2} \text { (Hofer-Moest react.) } \\
& 100-\mathrm{S}=\frac{1 / 4 \mathrm{CO}_{2}}{\mathrm{O}_{2}+1 / 4 \mathrm{CO}_{2}} \times 10^{2}
\end{aligned}
$$

Current efficiency ( $c E f f$ ), decomposition degree $(\mathrm{Z})$, anodic corrosion (Corr. $)^{6}$ ) were calculated by analyzing the concentration of $\mathrm{HOAc}\left(C_{\mathrm{HOAC}}\right), \mathrm{NaAc}\left(C_{\mathrm{NaOAc}}\right)$ or $\mathrm{Ni}^{2+}$ and $\mathrm{Fe}^{3+}$ with the ordinary method.

Table 1-a shows the result of the electrolysis of sodium acetate with nickel anode at ordinary condition.

Table 1-a Electrolysis of Sodium Acetate with Nickel Anode $\mathrm{NaOA}_{c}=210 \mathrm{~g} / l, D_{A}=12.5 \mathrm{~A} / \mathrm{dm}^{2}, t=13-16^{\circ} \mathrm{C}$

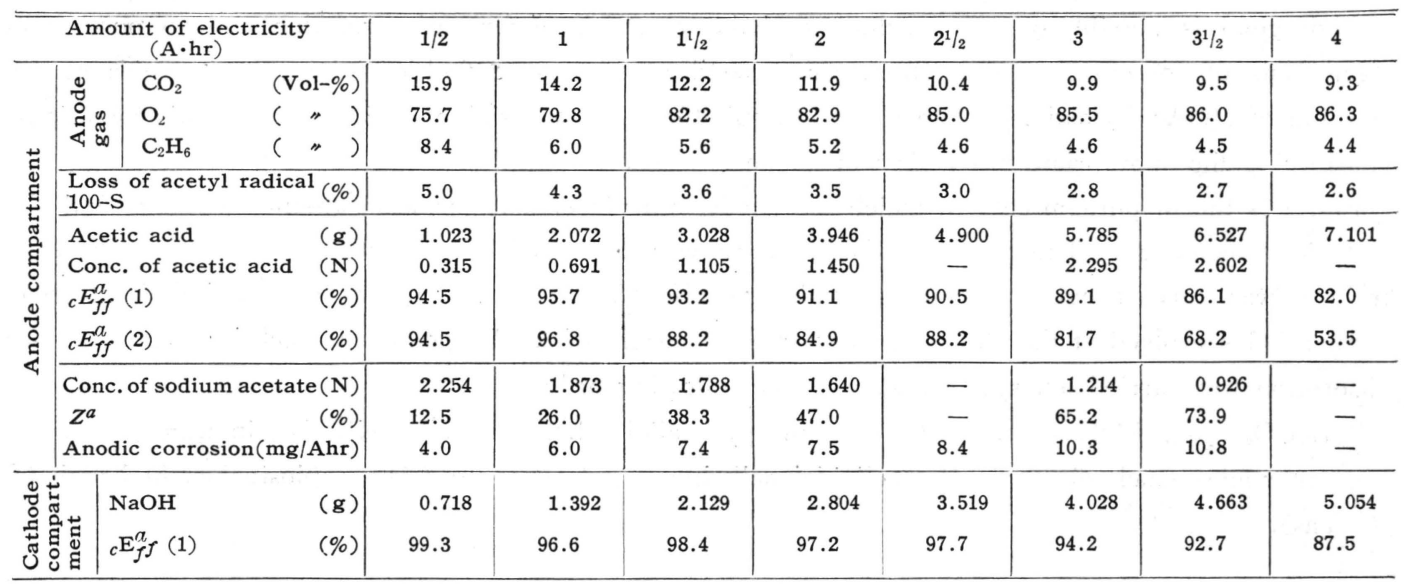

The material loss of acetyl radical was found to decrease from $5 \%$ to $2.5 \%$ with decreasing sodium acetate concentration and with increasing HOAc concentration in anolyte. The anodic corrosion of nickel $^{9)}$ uprised from $4 \mathrm{mg} / \mathrm{A} \cdot \mathrm{hr}$ to $11 \mathrm{mg} / \mathrm{A} \cdot \mathrm{hr}$ with increasing HOAc concentration in anolyte. Electrolytic results for the anodic decomposition degree were plotted in Fig. 2. The anodic current efficien-

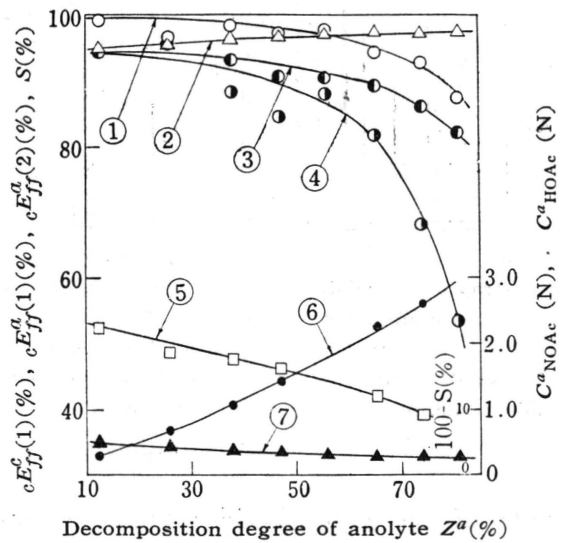
(1) Cathodic current efficiency $(1)_{c} E_{f f}^{c}(1)$
(5) $\mathrm{NaA}_{c}$ concentation $\left(C_{\mathrm{NaOA}}^{a}\right)$
(2) Yield of acetyl radical ( $\mathrm{s}$ )
(6) $\mathrm{HA}_{c}$ concentation $\left(C_{\mathrm{HOA}_{c}}^{a}\right)$
(3) Anodic current efficiency(1) $\left\{c E_{f f}^{a}(1)\right\}$ (7) Loss of acetyl radical (100-S)
(4) Anodic current efficiency(2) $\left\{c E_{f f}^{a}(2)\right\}$

Fig. 2 Electrolytic characteristics with a nickel anode 
cy was kept high (above 90\%) up to $50 \%$ of anodic decomposition degree.

Table 1-b shows the anode gas analysis for $1 / 4 \mathrm{~A} \cdot \mathrm{hr}$ range (quantity of electricity).

Table 1-b Anode Gas Analysis at the Interval of $1 / 4 \mathrm{~A} \cdot \mathrm{hr}$

(At the Same Electrolytic Condition Table 1-a.)

\begin{tabular}{|c|c|c|c|c|c|c|c|}
\hline $\begin{array}{c}\text { Amount of electricity } \\
(\mathrm{A} \cdot \mathrm{hr})\end{array}$ & $0-1 / 4$ & $1 / 4-2 / 4$ & $2 / 4-3 / 4$ & $3 / 4-1$ & $1-1^{1 / 4}$ & $1^{1 / 4}-1^{2 / 4}$ & $1^{2} / 4-1^{3 / 4}$ \\
\hline $\mathrm{CO}_{2} \quad(\mathrm{Vol}-\%)$ & 14.6 & 12.7 & 12.1 & 10.4 & 9.7 & 9.0 & 10.4 \\
\hline $\mathrm{O}_{2} \quad(" n)$ & 68.1 & 82.7 & 84.2 & 86.1 & 86.5 & 87.4 & 86.1 \\
\hline $\mathrm{C}_{2} \mathrm{H}_{6} \quad(" \prime)$ & $(17.3)$ & 4.6 & 3.7 & 3.5 & 3.8 & 3.6 & 3.5 \\
\hline $\begin{array}{c}\text { Amount of electricity } \\
(\mathrm{A} \cdot \mathrm{hr})\end{array}$ & $13 / 4-2$ & $2-2^{1 / 4}$ & $2^{1 / 4}-2^{2} / 4$ & $2^{2} / 4-2^{3 / 4}$ & $2^{3} / 4-3$ & $3-3^{1 / 4}$ & $3^{1 / 4}-3^{2} / 4$ \\
\hline $\mathrm{CO}_{2} \quad(\mathrm{Vol}-\%)$ & 8.2 & 8.2 & 7.9 & 7.9 & 7.5 & 7.1 & 7.7 \\
\hline$(")$, & 88.2 & 88.2 & 88.8 & 90.0 & 89.6 & 90.0 & 89.5 \\
\hline $\mathrm{C}_{2} \mathrm{H}_{6} \quad(" \prime)$ & 3.6 & 3.6 & 3.3 & 3.1 & 2.9 & 2.9 & 2.8 \\
\hline
\end{tabular}

Magnetite anode showed the same tendency as the nickel anode (Table 2). Anodic corrosion of magnetite anode ${ }^{10)}$ uprised from $4 \mathrm{mg} / \mathrm{A} \cdot \mathrm{hr}$ to $8.5 \mathrm{mg} / \mathrm{A} \cdot \mathrm{hr}$ with increasing HOAc concentration in the anolyte, but the material loss of acetyl radical was kept constant (about 3\%) during the electrolysis. Distribution of sodium in the electrolyzer was plotted in Fig. 3 (magnetite anode) against the quantity of elecricity ( $\mathrm{Na}$ distributes in anolyte as $\mathrm{CH}_{3} \mathrm{COONa}$, in diaphragm as $\mathrm{CH}_{3} \mathrm{COONa}$, in catholyte as $\mathrm{CH}_{3} \mathrm{COONa}$ or $\mathrm{NaOH}$ and in cathode as amalgam).

Table 2-a Electrolysis of Sodium Acetate with Magnetite Anode $\mathrm{NaOAC}=210 \mathrm{~g} / l, D_{A}=11.0 \mathrm{~A} / \mathrm{dm}^{2}, t=18-22^{\circ} \mathrm{C}$

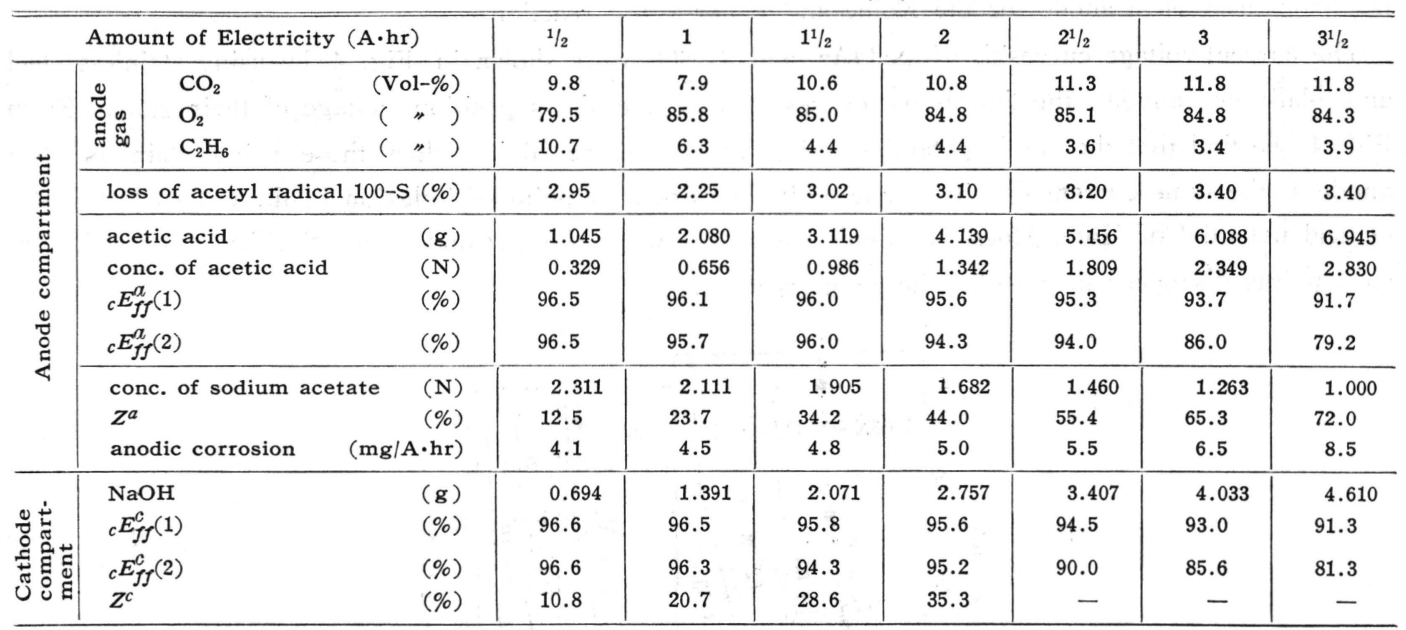

Table 2-b Anode Gas Analysis at an Interval of $1 / 4 \mathrm{~A} \cdot \mathrm{hr}$ with Magnetite Anode

(At the Same Electrolytic Condition as Table 2-a)

\begin{tabular}{|c|c|c|c|c|c|c|}
\hline Amount of electricity $(\mathrm{A} \cdot \mathrm{hr})$ & $0-1 /$ & $1 / 4-2 / 4$ & $2 / 4-3 / 4$ & $3 / 4-1$ & $1-1^{1 / 4}$ & $1^{1 / 4}-1^{2} / 4$ \\
\hline $\mathrm{CO}_{2} \quad(\mathrm{Vol}-\%)$ & 9.0 & 12.5 & 10.2 & 10.8 & 11.0 & 13.6 \\
\hline$(")$, & 80.1 & 84.7 & 86.9 & 86.3 & 85.7 & 84.1 \\
\hline $\mathrm{C}_{2} \mathrm{H}_{6} \quad(" \prime)$ & 10.9 & 2.8 & 2.9 & 2.8 & 3.3 & 2.3 \\
\hline Amount of electricity $(\mathrm{A} \cdot \mathrm{hr})$ & $1^{2} / 4-1^{3} / 4$ & $13 / 4-2$ & $2-2^{1 / 4}$ & $2^{1} / 4-2^{2} / 1$ & $2^{2} / 4-2^{3 / 4}$ & $23 / 4-3$ \\
\hline $\mathrm{CO}_{2} \quad(\mathrm{Vol}-\%)$ & 11.7 & 11.8 & 12.5 & 11.5 & 14.5 & 11.1 \\
\hline $\mathrm{O}_{2} \quad(" n)$ & 85.1 & 85.1 & 86.4 & 85.1 & 82.8 & 85.9 \\
\hline $\mathrm{C}_{2} \mathrm{H}_{6} \quad(" n)$ & 3.2 & 3.1 & 1.1 & 3.4 & 2.6 & 3.0 \\
\hline
\end{tabular}

Next, we examined the anode phenomena in order to decrease the material loss of acetyl radical by using various materials as the anode (metal, metal oxide or alloys of iron group metal). 


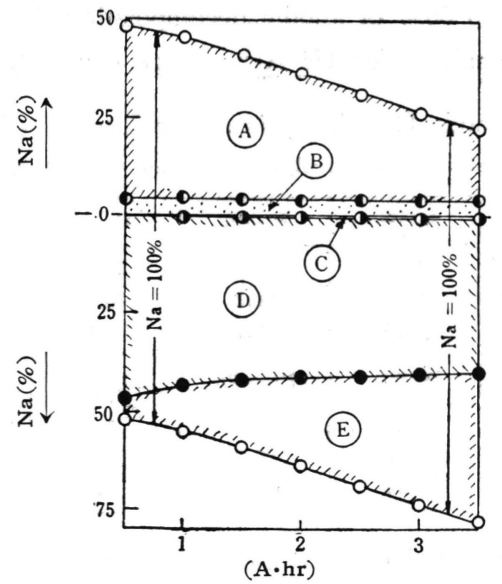

Na distribution : (A) as NaOAC in anolyte

(B) as NaOAC in diaphragm

(C) as $\mathrm{NaOH}$ in catholyte

(D) as NaOAC in catholyte

(E) as amalgam in cathode

Fig. 3 Distribution of sodium in the electrolyser

Stainless steel (18-11, 18-8, Cr-Ni type) is well known as durable material for acetic acid, dilute mineral acid, alkali etc. and is known to have a low oxygen-overvoltage. On the other hand, platinium is famous as typical anode for the Kolbe and Hofer-Moest reaction.

The current-voltage curves ${ }^{13)}$ of $\mathrm{NaOAc}$ and $\mathrm{H}_{2} \mathrm{SO}_{4}$ were shown in Fig. 4 by using stainless steel and platinium anode, the figures on curves showed the decomposition voltage of their salts. From Fig. 4, we find that the anode potentials using $\mathrm{Pt}$ anode are higher than those using stainless steel anode at the same current density. The noticeable break or point of inflexion in the curves (probably, critical potential of Hofer-Moest reaction) are visible when the Pt anode and $\mathrm{NaOAc}$ was used, but such points disappear in cases of the stainless anode.

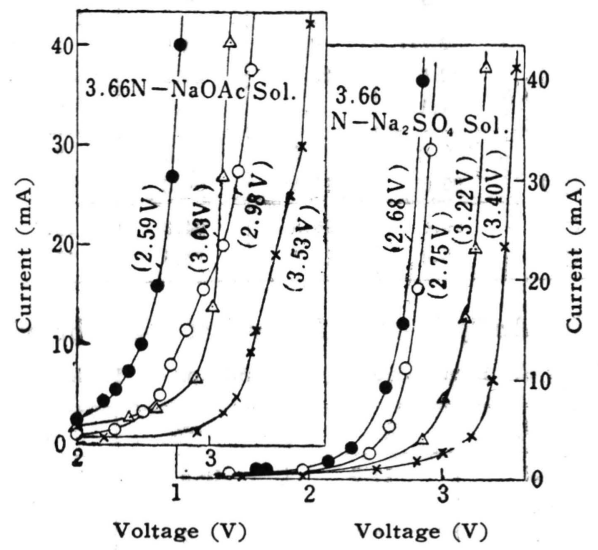

\begin{tabular}{l|l|l}
\hline \hline & \multicolumn{1}{|c|}{ Anode } & \multicolumn{1}{|c}{ Cathode } \\
\hline$-0-0-$ & $18-8$ stainless steel & $18-8$ stainless steel \\
$-O-O-$ & smooth Pt & $18-8$ stainless steel \\
$-\Delta-\Delta-$ & $18-8$ stainless & mercury \\
$-\times-\times-$ & smooth Pt & mercury
\end{tabular}

Fig. 4 Curent-voltage curves and decomposition voltage $\left(27 \pm 2^{\circ} \mathrm{C}\right)$ of the solution of $3.66 \mathrm{~N}-\mathrm{NaOAc}$ and $\mathrm{Na}_{2} \mathrm{SO}_{4}$ 


\section{Summary}

$\mathrm{NaOAc}$ solution was electrolysed with nickel and magnetite anode and with mercury cathode under ordinary electrolytic conditions of the diaphragm cell of a batch system. We found the possibility to obtain HOAc with good yields under ordinary conditions, by using the iron group metal or its alloy anode.

(1) Material loss of acetyl radical were $5 \sim 2.5 \%$ at nickel anode and constantly ca. $3 \%$ at magnetite anode.

(2) Current efficiency was kept very high (above 90\%) up to $50 \%$ of anodic decomposition degree with both anodes.

(3) Anodic corrosion increased with increase of the concentration of acetic acid, for example, $4 \mathrm{mg} / \mathrm{A} \cdot \mathrm{hr}$ when $\mathrm{HOAc}$ is $0 \%$ and $11 \mathrm{mg} / \mathrm{A} \cdot \mathrm{hr}$ when $\mathrm{HOAc}$ is ca. $10 \%$ and a $\mathrm{Ni}$ anode was used. On the other hand, the corrosion rate was $4 \mathrm{mg} / \mathrm{A} \cdot \mathrm{hr}$ when $\mathrm{HOAc}$ is $0 \%$ and $8.5 \mathrm{mg} / \mathrm{A} \cdot \mathrm{hr}$ when $\mathrm{HOAc}$ is ca. $10 \%$ and a magnetite anode was used.

(4) Anodic behavior in current-voltage curves of the stainless steel anode was examined, in comparison with that of $\mathrm{Pt}$ anode. The anodic potential for the discharge of the hydroxyl-ion $\left(\mathrm{O}_{2}\right.$ evolution) was found to be very low (at stainless steel). Finally, the appropriate mechanism of the anode phenomena was discussed.

\section{Literature :}

(Received Aug. 29, 1959)

1) S. Okada, T. Eguchi, Japan. Pat. 208257 (1954).

2) H. Kolbe, Ann. 69, 279 (1849), J. Chem. Soc. 2, 157 (1850); F. Foerster A. Piguet, Z. Elektrochem. 10, 729 (1904); S. Glasstone, A. Hickling, J. Chem. Soc. II, 1878 (1934), Trans. Faraday Soc. 31, 1656 (1935) ; F. Fichter, "Organische Elektrochemie" (1942) Steinkoff, Dresden.

3) H. Hofer, M. Moest, Ann. 323, 284 (1902), Z. Elektrochem 10, 833 (1904); F. Foerster, "Elektrochemie wässeriger Lösungen”" p. 856 (1923) J. Ambrosius Barth, Leipzig; J. Walker, J. Chem. Soc. 2040 (1928); S. Glasstone, A. Hickling, J. Chem. Soc. 2345, 2800 (1932), 829 (1933), 10,1772 (1934), 1453 (1936), 325 (1937).

4) J. Peterson, Z. Physik. Chem. 33, 90, 108,, 295, 698 (1900).

5) T. Kunugi, This Journal 20, 69, 111, 154 (1952).

6) E.P. Schoch, Trans. Faraday Soc. 9, 274 (1913); W.J. Müller, Trans. Faraday Soc. 27, 736 (1931) ; "Elektrochemisches Praktikum”, (1942), Steinkoff Dresden; E.S. Hedges, Z. Elektrochem. 40, 570 (1934), 41, 83, 641 (1935), 42, 166, 789 (1936).

7) J. Samejima, "Butsuri-kagaku Jikkenho" p. 138 (1939), Shōkabō, Tokyo.

8) "Handbook of Electrochemistry" p. 306 (1953) Maruzen, Tokyo.

9) Y. Ōtsuka, "Kihon Kagaku Bunseki” p. 339 (1943), Kyōgokushoten, Kyoto.

10) Ibid. p. 473 (1943), Kyoto.

11) S. Glasstone, J. Chem. Soc. II, 1878 (1934).

12) MacGillivary, J. Chem. Soc. I, 941 (1932).

13) S. Tanaka, "Denkikagaku Jikkenhō", p. 104 (1957), Uchidarōkakuho, Tokyo.

14) J. Walker, J. Chem. Soc. 2040 (1928); S.N. Shukula, J. Walker, Trans. Farady Soc. 27, 722 (1931); J. Walker, J. Weiss, Trans. Farady Soc. 31, 1011 (1935); J. Walker, E. Wild, J. Chem. Soc. 207 (1935), 1132 (1937). 